\title{
De meting van arbeids(dis)satisfactie op welvaartstheoretische basis
}

\author{
Naar een rekeningsysteem voor de kwaliteit van de arbeid
}

Dr: K. Tepla

\section{Inleiding}

Deze bijdrage bevat een samenvatting van mijn proefschrift Accounting for the Quality of Work-Life - Putting Price Tags on Sources of Job (Dis)Satisfaction. Hierin ontwikkel ik een rekeningsysteem voor het meten van arbeids(dis)satisfactie in termen van door de werknemers ervaren externe effecten. Deze zogenoemde welvaartstheoretische benadering van de maatschappelijke berichtgeving geldt al ruim twee decennia als conceptueel degelijk, maar praktisch onuitvoerbaar. Anderzijds kunnen meer werkbare vormen van maatschappelijke berichtgeving slechts ten dele voorzien in de behoefte aan (financiële) informatie over de kwaliteit van de arbeid, terwijl deze behoefte de laatste jaren sterk is toegenomen naar aanleiding van het hoge niveau van ziekteverzuim en (vooral psychische) arbeidsongeschiktheid.

Ik stel dat het welvaartstheoretisch principe wel technisch operationaliseerbaar is, waarmee ik bedoel: vertaalbaar naar empirische grootheden en processen. Tot deze conclusie kom ik op basis van een teleologische interpretatie van het maatschappelijk waarderingsproces, waarin de uit de welvaartseconometrie afkomstige inkomenswaarderingsvraag en welvaartsfunctie van het inkomen een sleutelrol spelen.

\section{Maatschappelijke berichtgeving}

\subsection{Classificatie van benaderingen}

De ingrijpende en nog steeds groeiende invloed van het bedrijfsleven op de maatschappij heeft ertoe geleid dat ondernemingen in toenemende mate worden beoordeeld op de kwaliteit van de winst. Vooral aan de wijze waarop zij omgaan met 'maatschappelijke productiefactoren' als arbeid en milieu worden steeds hogere wettelijke en morele eisen gesteld. Met andere woorden: de hedendaagse onderneming wordt geacht naast economische ook sociale en ecologische verantwoordelijkheden te hebben.

De maatschappelijke verantwoordelijkheid van het bedrijfsleven houdt op z'n minst een morele en ten dele ook een wettelijke - verslaggevingsplicht in die gestalte heeft gekregen in het verschijnsel soci(et)al accounting'. Voor 'the measurement and reporting, internal or external, of information concerning the impact of an entity and its activities on society' (Estes, 1976, p. 3) is de traditionele (bedrijfseconomische) financiële verslaggeving niet geschikt. Enerzijds is de reikwijdte (voornamelijk de financiële aspecten van markttransacties) te beperkt; anderzijds ontbreekt een maatschappelijk meetperspectief (kosten en baten worden vanuit het oogpunt van de ondememing gemeten). Hierdoor vallen niet-financiële aspecten van markttransacties alsmede door de onderneming veroorzaakte externe effecten (ongecompenseerde maatschappelijke kosten en baten ${ }^{2}$ - zie paragraaf 2.3) in hun geheel buiten de boot.

Inmiddels hebben pogingen gedurende bijna drie decennia om de maatschappelijke prestaties

Katerina Tepla is als fiscaal/bedrijfseconoom afgestudeerd aan de Erasmus Universiteit Rotterdam, op een scriptie over human resource accounting. Het proefschrift waarop zij in augustus 1996 promoveerde, schreef zij als AlO bij het Tinbergen Instituut en de vakgroep Kosten- en Winstbepalingsvraagstukken van de EUR. Momenteel volgt zij een kopstudie voor financieel SAP R/3-consultant. 
van de onderneming systematisch in kaart te brengen, een bonte verzameling societal accounting-modellen opgeleverd. Op basis van meetniveau kunnen drie hoofdcategorieën worden onderscheiden (Schreuder, 1981, p. 92), met daarbinnen - enigszins arbitrair - diverse benaderingen (Gray, Owen en Maunders, 1987, p. 93; Dekker, 1993, p. F 1750-9) en specifieke modellen:

1 identificatie en beschrijving (de kwalitatieve of narrative disclosure-categorie);

2 loepassing van meerdere meeteenheden (de niet-financiële kwantitatieve categorie), met de volgende varianten:

- de statistische of technische-databenadering; de indicatorenbenadering;

- de compliance-with-standards-benadering; de goal accounting-benadering;

3 toepassing van één meeteenheid (de integraalfinanciële benadering), met de volgende varianten:

de welvaartstheoretische benadering; de expenditure-oriented-benadering; de surplus accounting-benadering.

In mijn onderzoek staat de welvartstheoretische benadering centraal. Om deze keuze in perspectief te plaatsen, volgt eerst een schets van de indicatorenbenadering.

\subsection{De indicatorenhenadering - 'rupportcijfers' en kwalitatieve evaluaties}

Vooral met betrekking tot de kwaliteit van de arbeid wordt de indicatorenbenadering beschouwd als de beste combinatie van praktische uitvoerbaarheid en theoretische deugdelijkheid. Indicatoren kan men zich voorstellen als 'goal or need oriented refinements of statistics' (Gray, Owen en Maunders, 1987, p. 105). Met behulp van situationele indicutoren worden aspecten van de arbeidssituatie in objectieve termen beschreven, bijvoorbeeld het maandsalaris, het geluidsniveau op de werkplek of het aantal uren studieverlof per week. De werknemer drukt zijn of haar (subjectieve) mening over deze zaken uit door middel van belevingsindicatoren (zie Schreuder, 1981, pp. 133-135). Vaak wordt omwille van de veronderstelde interpersonele vergelijkbaarheid van de beoordelingen gebruikgemaakt van evaluatieschalen, zoals 'rapportcijfers' van 1 tot en met 10 of de reeks 'zeer slecht slecht - niet goed, niet slecht - goed - zeer goed'.
Een belangrijk pluspunt van de indicatorenbenadering is dat zij een tweeledig beeld - beschrijvend én sturend - geeft van vrijwel alle aspecten van het werk. De evaluaties geven aan waar de onderneming de situationele voorwaarden voor een optimale arbeidsbeleving eventueel zou kunnen verbeteren (arbeidssatisfactie als zodanig is namelijk niet rechtstreeks 'maakbaar'). De validiteit van belevingsindicatoren wordt echter in twee opzichten potentieel bedreigd. Ten eerste rijst de vraag of een bepaalde evaluatie wel door iedereen gelijk wordt geïnterpreteerd, met andere woorden: de vraag of verschillende mensen dezelfde meetschaal voor welzijn hanteren. Verstaat iemand die makkelijk het predikaat 'goed' geeft, daar gevoelsmatig wel hetzelfde onder als iemand die slechts bij hoge uitzondering iets 'goed' vindt (zie Agho, Price en Mueller, 1992, pp. 186, 192)'? De tweede potentiële oorzaak van invalide satisfactiemetingen is het menselijk aanpassingsvermogen in het streven naar maximaal welzijn. Wie ontevredenheid opvat als een teken van eigen falen, zal geneigd zijn zich tevreden voor te doen zonder dat echt te zijn (Seashore, 1974, p. 158).

Volgens sommigen is het grootste nadeel van de indicatorenbenadering het ontbreken van een gemeenschappelijke noemer voor de situationele metingen. Guldens (salaris), vierkante meters (werkruimte) en diploma's (moeilijkheidsgraad van het werk) kan men nu eenmaal niet bij elkaar optellen, en bovendien kan op basis van nietfinanciële indicatoren geen kosten/baten-beoordeling van eventuele verbeteringsmaatregelen plaatsvinden. Aangezien bedrijfseconomische kosten en baten reeds in geldeenheden luiden, ligt het voor de hand om deze meeteenheid ook voor maatschappelijke kosten en baten te gebruiken.

\subsection{De welvaartstheoretische benadering - maatschappelijke versus bedrijfseconomische kosten en baten}

De eerste generatie societal accounting modellen - de zogenoemde welvaartstheoretische benadering - had een simpel, maar theoretisch waterdicht uitgangspunt: het begrippenraamwerk van de financiële verslaggeving toepassen op hetzij externe effecten, hetzij alle (zowel gecompenseerde als ongecompenseerde) maatschappelijke kosten en baten. Zo ontstonden maatschappelijke staten van toegevoegde waarde (Seidler, 
1973; Solomons, 1974), maatschappelijke balansen (Eichhorn, 1974) en maatschappelijke resultatenrekeningen (Eichhorn, 1974; Estes, 1976).

In een welvaartstheoretisch model worden bedrijfseconomische (op marktprijzen gebaseerde) en maatschappelijke waarderingen van kosten en baten tegenover elkaar gesteld. Hierbij fungeren de bedrijfseconomische waarderingen (ofwel 'harde guldens'-bedragen) als financiële situationele indicatoren en zijn de in 'zachte guldens' luidende maatschappelijke waarderingen te beschouwen als financiële belevingsindicatoren.

Een verschil tussen deze twee waarderingen wijst op het bestaan van een extern effect. Met andere woorden: door de activiteiten van de onderneming ontstaan er voor- respectievelijk nadelen voor derden (andere ondernemingen, gezinnen, de maatschappij in het algemeen), waarvoor de onderneming van de begunstigden geen vergoeding ontvangt respectievelijk aan de benadeelden geen vergoeding betaalt (zie Bulte en Van der Wal, 1987, p. 129). Bulte en Van der Wal verklaren tevens de benaming externe effecten: 'Deze effecten staan als het ware buiten het marktmechanisme.'

Men kan twee soorten externe effecten onderscheiden:

- 'echte' of 'losse' externe effecten, waar compensatie (vergoeding) van het maatschappelijk nadeel (voordeel) - en daarmee enig verband met een markttransactie - geheel ontbreekt;

producenten- respectievelijk consumentensurplussen of -tekorten, waar sprake is van gedeeltelijke compensatie of vergoeding in het kader van een markttransactie.

Uit de Social Impact Statement van Estes (1976, pp. 96-97) blijkt - op uiteenlopende aggregatieniveaus - in welke mate de maatschappelijke kosten en baten worden gecompenseerd of vergoed. De Gesellschaftsbezogene Erfolgsrechming (maatschappelijke resultatenrekening) en Gesellschaftsbezogene Bestandsrechnung (maatschappelijke balans) van Eichhorn (1974a, p. 54 respectievelijk 1974b, p. 95) geven de 'netto' externe effecten weer; de achterliggende bedrijfseconomische en maatschappelijke waarderingen worden niet vermeld. Het saldo van de externe effecten wordt door zowel Eichhorn als Estes opgevat als een maatstaf voor de (positieve of negatieve) maatschappelijke bijdrage van de onderneming.
Omdat zowel de 'bruto'- als de 'netto'presentatiewijze nuttige informatie verschaft, bestaat mijn voorstel voor een welvaartstheoretische maatschappelijke jaarrekening uit een combinatie van de modellen van Estes en Eichhorn (zie Tepla, 1996, pp. 237 en verder).

De welvaartstheoretische modellen leken haast te mooi om waar te zijn. En die vrees bleek gegrond: pogingen tot operationalisering leidden tot de aanbeveling de conceptuele ruggengraat van deze benadering - het mechanisme voor de bepaling van de maatschappelijke waarderingen althans voorlopig 'louter als analytische constructie' te beschouwen (zie Schreuder, 1981, p. 115116; 1979, p. 111: paragraaf 4 van deze bijdrage).

Nadat de welvaartstheoretische benadering aldus praktisch was doodverklaard, richtten soci(et)al accountants zich op vormen van maatschappelijke berichtgeving die vooral praktisch uitvoerbaar waren, zoals de indicatorenbenadering.

Alvorens na te gaan of de welvaartstheoretische benadering niet kan worden gerehabiliteerd, beschouw ik in de volgende paragraaf externe effecten als maatstaf voor de kwaliteit van de arbeid.

\section{De kwaliteit van de arbeid in termen van externe effecten}

De ultieme maatstaf voor de kwaliteit van de arbeid is arbeids(dis)satisfactie. In hoeverre kan men externe effecten in de arbeidsrelatie beschouwen als belevingsindicatoren van werknemerswelzijn?

Als werknemer is men economisch gezien zowel producent van diensten als consument van salaris, secundaire arbeidsvoorwaarden en werkintrinsieke beloningen. Eventuele consumentensurplussen en/of -tekorten in de diverse nietfinanciële beloningscomponenten vormen - tenzij zij elkaar precies compenseren - tezamen een producentensurplus of -tekort.

Naar mijn mening kan (de afwezigheid van) een door de werknemer ervaren extern producenteneffect als volgt in termen van welzijn worden geïnterpreteerd:

Een producentensurplus wijst op het bestaan van sterke arbeidssatisfactie. De werknemer voelt zich eigenlijk overbetaald en zou bereid zijn, bij gelijkblijvende arbeidsinhoud, -omstandigheden, -verhoudingen en niet- 
financiële beloning een lager loon of salaris te aanvaarden.

Een producententekort impliceert dat de werknemer ontevreden is. Gelet op de overige aspecten van het werk vindt hij of zij zichzelf onderbetaald. In principe beletten slechts bijvoorbeeld een opzegtermijn, concurrentiebeding of plaatsgebondenheid wegens privéomstandigheden zijn of haar vertrek naar een (relatief) 'betere" baan.

Als er geen producentensurplus of -rekort bestaat. is de werknemer in beginsel tevreden met zijn of haar huidige werksituatie. maar zou geen lager loon of salaris accepteren.

\section{Het welvaartstheoretisch waarderingsvraagstuk}

Zoals in paragraaf 2.3 al is aangegeven struikelden de welvaartstheoretische modellen over het gebrek aan een operationeel mechanisme voor de bepaling van de 'zachte guldens'-waarderingen. 'Harde guldens'-waarderingen zijn soms kant-en-klaar voorhanden, bijvoorbeeld wanneer de onderneming voor haar werknemers een voordelig collectief verzekerings- of OV-contract afsluit. Daarnaast zullen kosten/baten-analyses die aan begrotingen ten grondslag liggen wellicht nuttige gegevens bevatten over de bedrijfseconomische kosten en baten van (overwogen) veranderingen in de werksituatie, bijvoorbeeld de aanschaf van ergonomisch kantoormeubilair.

Theoretisch wordt de maatschappelijke waarde van een effect bepaald door een cardinale maatschappelijke welvaurtsfinctie (MWF). Deze kan men zich voorstellen als een soort supercomputer die geprogrammeerd is met alle informatie over de voorkeuren en omstandigheden van alle individuen in de samenleving. Uit deze gegevens kan de MWF voor elk denkbaar effect een maatschappelijke waarde berekenen.

In de praktijk beschikken wij echter niet over een gaaf exemplaar van deze conceptuele ruggengraat van de welvaartstheoretische maatschappelijke berichtgeving. Wel kunnen wij proberen de werking van een MWF 'handmatig' na te bootsen. Zo kwam ik tot een driestaps teleologische interpretatie van een zogenoemde Bergson-Samuelson Individualistic - ofwel van individuele voorkeuren uitgaande Social Welfare Function (zie Samuelson, 1977). De formule hiervoor wordt weergegeven in figuur 1.
Figun 1: Teleologische interpretatie van een maatschappelijke welvartsfunctie

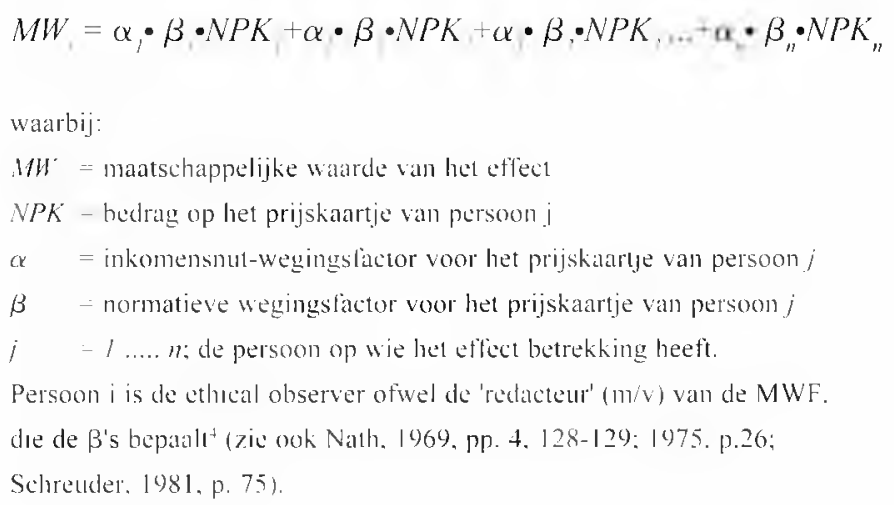

Ik stel dus voor het begrip maatschappelijke waarde van een effect te operationaliseren als de duhbelgewrogen som van de individuele mutsprijskaartjes (NPK's).

Door middel van een NPK drukt de werknemer zijn of haar nutswaardering voor (ofwel welvaartsevaluatie van) een bepaald aspect van de arbeidssituatie in geldtermen uit. Hiertoe wordt gebruikgemaakt van een hypothetische (veiling)markt” voor potentiële bronnen van arbeidssatisfactie of -dissatisfactie, met de werknemer in de rol van "koper" of "verkoper". De NPK's geven dan respectievelijk weer: Willingness-To-Pav (WTP: betalingsbereidheid) voor de (voortdurende) aanwezigheid van een bron van arbeidssatisfactie, dan wel voor de verwijdering of voortdurende atwezigheid van een bron van arbeidsdissatisfactie Willingness-To-Accept (WTA; bereidheid tot het aanvaarden van compensatie) voor de (voortdurende) afwezigheid van een bron van arbeidssatisfactie, dan wel voor de creatie of voortdurende aanwezigheid van een bron van arbeidsdissatisfactie (zie Dasgupta en Pearce, 1972. p. 123: Milne, 1991. p. 97).

Deze waarderingstechniek, in de literatuur bekend als de contingent valuation method (CVM; zie Hoevenagel, 1994), heeft als belangrijk psychologisch voordeel dat er niet rechtstreeks wordt gevraagd naar tevredenheid of ontevredenheid (zie paragraaf 2.3).

Aan de andere kant bestaat de mogelijkheid dat een effect over- of ondergewaardeerd wordt. omdat de werknemer ethische bezwaren heeft tegen de door de onderzoeker gekozen 'richting' van de hypothetische transactie. Maar ethische principes 
verschillen: zo zal de ene niet-roker weigeren te 'moeten betalen' voor een rookvrije werkplek, terwijl een ander absoluut niet wenst te worden 'omgekocht' om de rokers hun gang te laten gaan.

Bij de waardering van milieugoederen - de bakermat en tevens het voornaamste toepassingsgebied van de contingent valuation method wordt meestal de WTP-formulering gehanteerd en doorgaans redelijk valide bevonden (zie Milne, 1991, p. 98; Hoevenagel, 1994, pp. 208211). Een WTA-bedrag acht men over het algemeen minder betrouwbaar, met name omdat deze grootheid - in tegenstelling tot WTP die begrensd wordt door de Ability-To-Pay - geen 'natuurlijke' limiet kent. En evenals niet-financiële belevingsindicatoren zijn de (mondeling/schriftelijk/ per computer) opgegeven NPK's niet rechtstreeks verifieerbaar door de maatschappelijk accountant.

De fatale tekortkoming van de welvaartstheoretische modellen ligt echter in de tweede stap van het maatschappelijke waarderingsproces: het omrekenen van de individuele financiële waarderingen naar een qua nut (welzijn) homogene geldeenheid. Om redenen die in paragraaf 5 an de orde komen, zijn de nominale bedragen van de NPK's niet zonder meer vergelijkbaar in nutstermen. Dit geldt zowel voor de interpersonele vergelijking (tussen meerdere personen op één tijdstip), als voor de intertemporele vergelijking (voor één persoon tussen meerdere tijdstippen). Tot dusver werd met name interpersonele nutsvergelijking - nodig voor de bepaling van de $\alpha$ 's in de MWF-formule - door velen onmogelijk geacht. Zo schreef Schreuder: 'The measurement and valuation problems caused mainly by the impossibility of interpersonal and intertemporal comparisons of utility have as yet not been sufficiently met by economic theory to render [the welfare-theoretic] approach [...] practical' (1979, p. 111).

In theorie wordt de omrekening van alle NPK's naar dezelfde geldelijke nutseenheid gevolgd door aggregatie van de 'psychisch homogene' geldbedragen. De MWF-formule gaat uit van aggregatie per effect (aspect van de werksituatie), maar naar gelang de behoeften van de informatiegebruiker kan dit ook bijvoorbeeld per werknemer geschieden. Impliciet of expliciet wordt vooral bij interpersonele aggregatie een tweede set wegingsfactoren toegepast. Voor verslaggevingsdoeleinden mogen mijns inziens alle B's op 1 worden gesteld; in een besluitvormingscontext echter kan het voorzichtigheidshalve wenselijk zijn om de 'financiële stemmen' van de tegenstanders/benadeelden van een (ingrijpend en/of duurzaam) effect zwaarder te laten wegen dan die van de voorstanders/begunstigden. Op de vragen hoe en door wie de B's dienen te worden bepaald ga ik niet in, omdat zij in mijn ogen buiten het bestek van de technische operationaliseerbaarheid vallen.

\section{De rechtstreekse onvergelijkbaarheid van nutsprijskaartjes}

In geld uitgedrukte nutswaarderingen zijn dus niet zonder meer rechtstreeks vergelijkbaar in welzijnstermen. Om de precieze oorzaak hiervan te achterhalen, gaan wij nu een NPK 'ontleden'.

Een WTP/WTA-bedrag blijkt te zijn opgebouwd uit een aantal componenten:

de intrinsieke nutswaarde van het onderwerp van de hypothetische markttransactie voor de werknemer (met andere woorden: de welzijnsstijging of -daling die het effect bij hem of haar veroorzaakt);

- het werkelijke nominale inkomen van de '(ver)kopende' werknemer, dat als referentiekader dient. Mensen plegen namelijk te denken in termen van de eigen huidige financiële situatie (Van Praag, 1989, p. 19; Van der Sar, 1991, p. 27);

- het marginale nut van het inkomen (MNI), ofwel de nutswaarde van een extra geldeenheid voor de werknemer in kwestie. Belangrijke determinanten van het MNI zijn: de koopkracht van het nominale inkomen; het MNI is dus deels afhankelijk van het nominale inkomensbedrag;

- persoonlijke omstandigheden van de werknemer die de kosten van levensonderhoud van zijn of haar huishouden bepalen, zoals gezinsgrootte en -samenstelling (Van der Sar, 1991, p. 27); psychische factoren, zoals de mate waarin de werknemer een materialistische levenshouding heeft (zie Locke, 1969, p. 326).

Bij interpersonele en/of intertemporele verschillen zijn de NPK's niet rechtstreeks vergelijkbaar in termen van intrinsieke nutswaarde. Het is evenwel belangrijk om te beseffen dat deze 
heterogeniteit van het marginale nut van het inkomen slechts een symptoom is van de onvergelijkbaarheid. De oorzaak ligt in het gebruik van geld als een indirecte meeteenheid voor nut, omdat er sterk wordt getwijfeld aan het bestaan van een externe meetlat en een directe meeteenheid. Luce en Raiffa schetsen het probleem door cardinale nutsmeting met lengtemeting te vergelijken: 'The big difference between utility and length measurement is that we do not seem to have any 'outside thing' which can be measured by [different] persons to ascertain the relationship between the units [in which their respective measuring rods for utility are marked]' (1957, pp. 33-34). Nochtans weigerden zowel deze auteurs als bijvoorbeeld Dasgupta en Pearce (1972, p. 42) en Schreuder (1979, p. 111; zie het citaat in paragraaf 4) de mogelijkheid van cardinale nutsmeting volledig uit te sluiten.

En inderdaad, nog voordat de eerste welvaartstheoretische modellen het daglicht hadden gezien, was het probleem van de cardinale vergelijking van inkomensnut wat Van Praag betreft opgelost.

\section{De inkomenswaarderingsvraag en de welvaartsfunctie van het inkomen}

Met de inkomenswaarderingsvraag (Income Evaluation Question - IEQ) heeft Van Praag in 1968 een instrument ontwikkeld 'dat kan worden gebruikt om het concept nut van inkomen te operationaliseren'(Van der Sar, 1991, p. 195). Zoals figuur 2 laat zien, is een IEQ eenvoudig van opzet.

\section{Figuur 2: Voorbeeld van een inkomenswaarderingsvraag}

Rekening houdend met mijn (onze) omstandigheden, acht ik een netto totaal huishoudelijk inkomen per week / maand / jaar* van omstreeks
$f$.......... zeer slecht
$f \ldots \ldots . . . . \quad$ slecht
$f$........... onvoldoende
$f$.......... voldoende
$f$.......... goed
$f \ldots \ldots \ldots . \quad$ zeer goed

" Gekozen referentieperiode omcirkelen a.u.b.

Bron: Eigen vertaling van Van Praag (1989, p. 9)
Zes evaluaties blijkt de ideale schaallengte te zijn: lang genoeg om gelijke schaalintervallen te kunnen suggereren (wat uiteraard ook 'regelmatig' geformuleerde evaluaties vereist), kort genoeg om de respondenten niet te verwarren met gevoelsmatig nauwelijks te onderscheiden beoordelingen en zonder expliciet middelpunt (zie Van Praag, 1989, p. 10; Van der Sar en Van Praag, 1993, pp. 189, 198).

Op basis van de IEQ-gegevens wordt met behulp van regressie-analyse een individuele 'welvaartsfunctie van het inkomen' (Welfare Function of Income - WFI) geschat. Hierbij gaat men uit van twee veronderstellingen:

gelijke intervallen op de evaluatieschaal (de Equal Interval Assumption - EIA), ofwel intervalgeschaalde evaluaties (Van Praag, 1989, pp. 11-14; Antonides, Kapteyn en Wansbeek, 1980, in Kapteyn en Wansbeek, 1985a, p. 345);

- een lognormale inkomensverdeling, met andere woorden: de natuurlijke logaritmen van de inkomensbedragen worden geacht een normale kansverdeling te vormen (Van Praag, 1989, p. 15; Kapteyn en Wansbeek, 1985a, p. 345).

'Gelijke intervallen op de evaluatieschaal' betekent dat de gevoelsmatige afstand tussen twee kwalitatieve evaluaties steeds gelijk is. Onder anderen Van Praag (1989, pp. 11-14) heeft proefpersonen de reeks (discrete) evaluaties op een vijfpunts-IEQ laten 'vertalen' naar vijf waarden op een kwantitatieve continue schaal, bijvoorbeeld de getallen 1 tot en met 1000 . Hij constateerde een algemene tendens de numerieke schaal in vijf gelijke intervallen te delen (intervalschaal) en elk van deze intervallen door de middelste waarde aan te duiden. Hieruit concludeerde Van Praag dat de antwoordbedragen op een IEQ de middelpunten van inkomensintervallen zijn.

Bovendien bleek uit het contextvrije 'vertaalexperiment' dat regelmatig gespatieerde kwalitatieve evaluaties in principe als intervalschaal werden opgevat, en dus door een kwantitatieve continue schaal mogen worden vervangen (zie figuur 3). Van Praag hanteert een homogene $[0,1]$ schaal, waar 0 en 1 voor 'kan niet slechter' respectievelijk 'kan niet beter' staan. Deze bewerking vergemakkelijkt de toepassing van statistische technieken tijdens het schatten van de WFI. 
De lognormaliteit van een inkomensverdeling bepaalt de grafische S-grondvorm van de WFI en drukt uit dat inkomensbedragen worden geëvalueerd aan de hand van hun relatieve positie binnen de door de respondent waargenomen inkomensverdeling (zie Kapteyn en Wansbeek, 1985a, pp. 346-349).

Figuur 3: Een 'welvaartsfunctie van het inkomen'

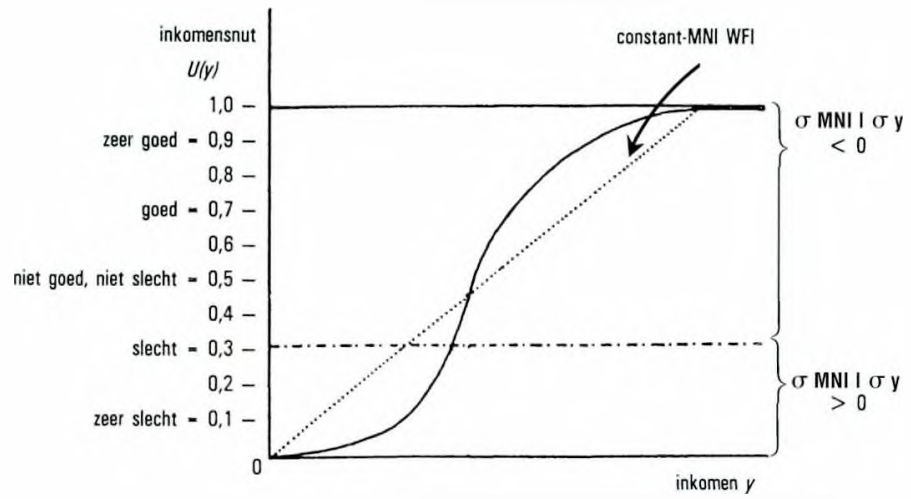

Dat inkomensverdelingen niet homogeen zijn (evenveel personen met een bepaald inkomen), noopt tot een bijzondere interpretatie van de equal interval assumption. De inkomensintervallen zijn niet even groot in lineaire zin (bijvoorbeeld steeds $f 2500$ 'breed'), maar in kansverdelingstermen (even 'dichtbevolkt' door inkomenstrekkers).

Op de rol van de IEQ/WFI bij de bepaling van maatschappelijke kosten en baten kom ik in paragraaf 7 terug. Hierna volgt nog een bespreking in vogelvlucht van deze econometrische instrumenten, die oorspronkelijk werden ontwikkeld voor het analyseren van inkomensverdelingen in welzijnstermen. Al ruim 25 jaar worden de IEQ/WFI zowel in Europa als in de Verenigde Staten op grote schaal toegepast bij onderzoek naar inkomensbeleid en armoede. Deze populariteit wordt voor een niet onbelangrijk deel verklaard door de eenvoud en geringe kosten van implementatie (Kapteyn en Wansbeek, 1985a, p. 334; Van der Sar, 1991, p. 32).

Weliswaar is de equal interval assumption voorzover mij bekend nog niet formeelstatistisch bevestigd. Het gaat echter om een kleine marge, die men toeschrijft aan de voorzichtigheid van respondenten bij hun eerste poging tot schaalindeling: opdat er voldoende schaalruimte overblijft voor de latere intervallen, worden de eerste intervallen relatief klein gehouden (Van Praag, 1989, pp. 13, 17).

In welvaartseconometrische kringen lijkt men niet al te zwaar aan deze achilleshiel te tillen, getuige de uitspraak van Van der Sar: 'Thus far the results [of the IEQ] are consistent and there is no reason to doubt its validity' (1991, p. 32).

\section{Vergelijking van geldbedragen in nutstermen met behulp van de IEQ/WFI}

Hoe passen de IEQ en de WFI nu in het plaatje van het welvaartstheoretisch waarderingsvraagstuk?

De evaluatieschaal van de IEQ vormt naar mijn mening de in paragraaf 5 gezochte externe meetlat voor inkomensnut, terwijl men de $\alpha$ 's (inkomensnutwegingsfactoren) uit de MWF-formule kan bepalen aan de hand van WFI's. De helling van een WFI (gelijk aan de verandering in inkomensnut gedeeld door inkomensverandering) bij een bepaald inkomensbedrag geeft namelijk het gemiddelde marginale nut van dat bedrag voor de respondent, en de $\alpha$ 's zijn MNI-ratio's weer.

De berekening van de $\alpha$ 's alsmede de omrekening van de NPK's naar een geldelijke standaardnutsnoemer laten zich het duidelijkst uitleggen in grafische termen, uitgaande van overdreven hoge NPK's en met afronding van cijfers ${ }^{6}$.

Eenvoudigheidshalve beperken wij ons tot twee personen, $\mathrm{A}$ en $\mathrm{B}$, wiens respectievelijke WFI's, uitgangsinkomens ( $f 20.000$ respectievelijk $f 8.300$ ) en WTP-NPK's ( $f 3.300$ respectievelijk $f 2.200$ ) in figuur $4 \mathrm{a}$ en $4 \mathrm{~b}$ worden weergegeven. Wij kiezen A's WFI als standaardnutsnoemer en gaan dus B's NPK omrekenen. In de figuren wordt de vertaling van NPK's naar nutsdalingen $(0,13$ respectievelijk 0,2$)$ aangegeven met stippellijntjes.

B's omgerekende NPK is het bedrag dat bij A's WFI en uitgangsinkomen B's eigen nutsdaling van 0,2 inhoudt (figuur $4 \mathrm{c}$ ). Deze nutsdaling trekken wij dus af van A's uitgangsnutsniveau, 'vertalen' de uitkomst naar inkomenstermen ( $f$ 15.000) en komen tot een omgerekend NPK voor B van $f$ 5.000. Dat B's NPK na omrekening een hoger bedrag aangeeft dan dat van A viel te verwachten: in nutstermen is B's WTP immers groter dan die van A. 
Figun! 4: Omrekening ian mutsprijskaartjes mot behulp van welvartstuncties van het inkomen
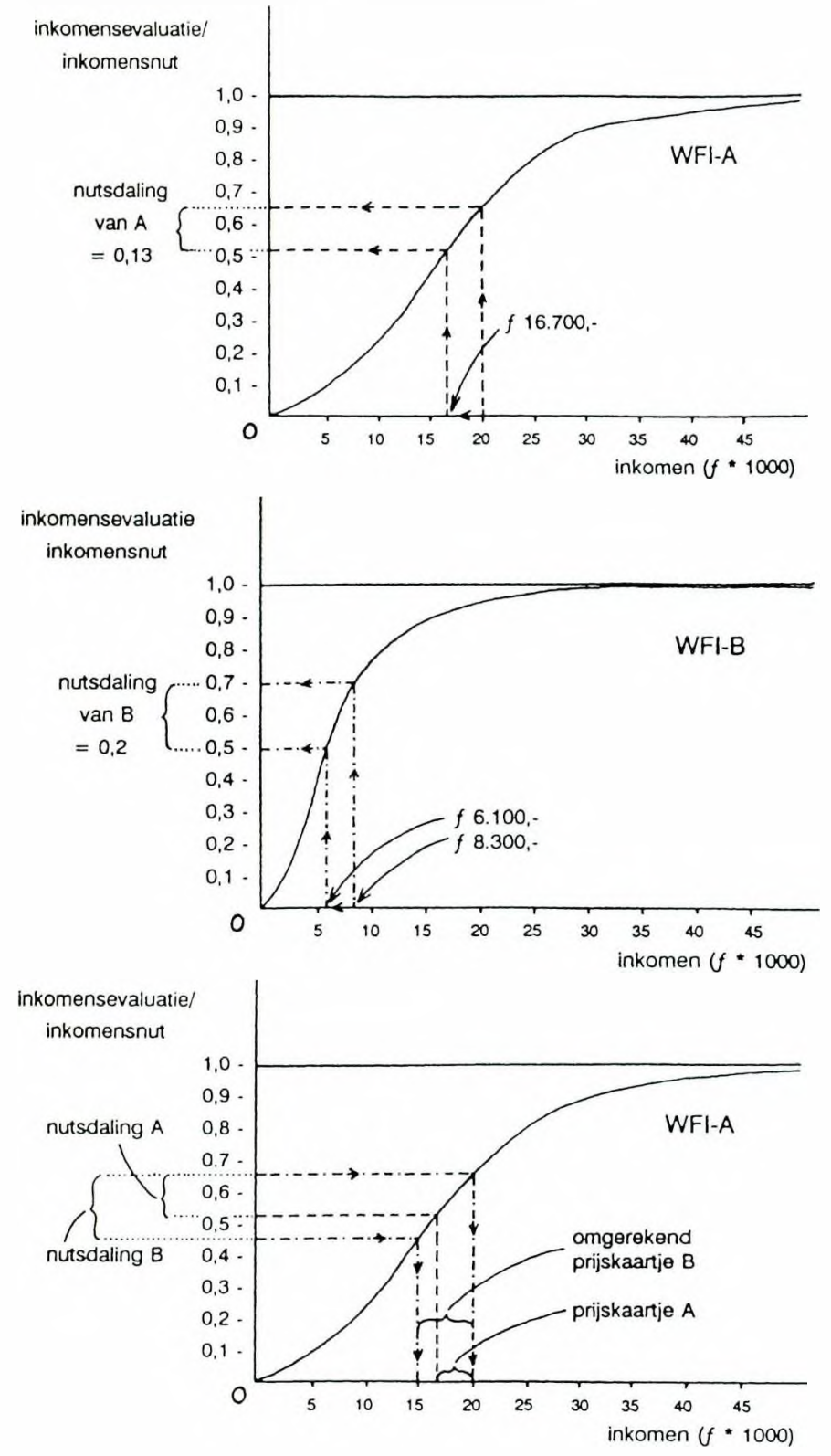

In de MWF-formule is de $\alpha$ van $\Lambda$ gelijk aan I, omdat A's NPK al in termen van de standaardnutsnoemer luidt. B`s $\alpha$ is gelijk aan:

gemiddeld MNI-B over traject NPK-B

gemiddeld MNI-A over traject NPK-A

gemiddelde helling WFI-B over traject NPK-B

gemiddelde helling WFI-A over traject NPK-A

nutsdaling $\mathrm{B}-$ inkomensdaling $\mathrm{B}$

$=\overline{\text { nutsdaling } \mathrm{A} \div \text { inkomensdaling } \mathrm{A}}$

$$
\begin{aligned}
& =\frac{(0,7-0.5) \div(f 8.300-f 6.100)}{(0,66-0.53)-(f 20.000-f 16.700)} \\
& \approx 0,000091-0.00003,9 \approx 2.3
\end{aligned}
$$

Ter verificatie: B's echte NPK $(f 2.200)$ maal $\mathrm{B}$ 's $\alpha$ (ongeveer 2.3$)=$ (ongeveer) $f 5.060$.

Voor de goede orde zij tevens vermeld, dat in tegenstelling tot mijn eerdere beweringen (Tepla, 1994, p. 30)-wij WFI's niet kunnen gebruiken voor integrale nutsvergelijkingen van inkomensbedragen. Een intervalschaal kent immers het hiervoor benodigde vaste nulpunt niet.

\section{Een analogic}

In welvartseconom(etr)ische kringen mogen de IEQ/WFI als algemeen aanvaard gelden, de vraag is hoe traditionele (financial) accountants zouden denken over de toepassing van deze instrumenten in het kader van de maatschappelijke berichtgeving. Zouden zij dan hun afkeurende mening over de technische operationaliseerbaarheid van de welvaartstheoretische modellen (ten dele) herzien?

Om mogelijke argumenten vóór en tegen goedkeuring van de IEQ/WFI in voor linancial accountants herkenbare termen te formuleren, koos ik voor een analogie tussen nut/welzijn en winst. Deze aanpak werd ingegeven door Hartogs (1973, pp. 2-3) constatering dat nut en winst dezelfde rol - die van de axiomatisch te maximeren doelvariabele - spelen in welvaartstheorie respectievelijk micro-economische prijstheorie. Door nut op te vatten als 'psychologische winst'. kon ik laten zien dat nutsvergelijking met behulp van de IEQ/WFI in vele opzichten overeenkomsten vertoont met twee in de financiële verslaggeving toegepaste meeteenheidstandaardisatieprocedures:

de omrekening van in rreemde valuta luidende bedragen - de omrekenwisselkoersen hebben hier dezelfde functie als de $\alpha$ 's bij interpersonele nutsvergelijking:

de koopkiachicorrectie bij (sterke) inflatie of deflatie - hiertoe gebruikt men ratio's van prijsindexcijfers op dezelfde wijze als de $\alpha$ 's bij intertemporele nutsvergelijking.

Hierna worden de hoofdlijnen van de analogie puntsgewijs geschetst (zie Tepla. 1994. pp. 3031). De beperkingen van deze beschouwing - en welke betekenis zij mijns inziens hebben - zet ik in paragraaf 9 uiteen. 


\section{Rekeneenheid}

In de externe verslaggeving rekent men in termen van economische koopkracht van één valuta.

De rekeneenheid in de welvaartstheoretische maatschappelijke berichtgeving is het inkomensmut ('psychische koopkracht') van de standaard-WFI.

\section{Situationeel ijkpunt}

Economische koopkracht is omgekeerd evenredig met 'het algemene prijspeil'. Prijsindexcijfers voor een gegeven valuta worden berekend aan de hand van een 'goederenmandje' met (nagenoeg) gelijkblijvende inhoud.

Bij psychische koopkracht vormt de reeks verbale evaluaties in de IEQ de externe meetlat.

Oorzaak van gelijktijdige onvergelijkbaarheid van nominale geldbedragen

Bedragen die in eenheden van verschillende valuta luiden, zijn niet rechtstreeks vergelijkbaar in koopkrachttermen.

Interpersonele verschillen in inkomensnut betekenen dat de NPK's van verschillende personen niet in dezelfde 'nutsvaluta' luiden.

Oorzaak van volgtijdige onvergelijkbaarheid van nominale geldbedragen

Door inflatie (deflatie) daalt (stijgt) de economische koopkracht van de geldeenheid van een valuta.

Intertemporele verschillen in inkomensnut bij één persoon kunnen ontstaan als gevolg van veranderde (privé- of beroeps)omstandigheden enlof psychische factoren.

Ratio's voor de omrekening van nominale geldbedragen naar een homogene rekeneenheid

In het kader van constant-purchasing-power accounting worden ratio's van prijsindexcijfers gebruikt om alle nominale bedragen in geldeenheden van gelijke koopkracht uit te drukken. 'Vertaling' van bedragen van een vreemde naar de eigen valuta geschiedt met behulp van (omreken)wisselkoersen.

De $\alpha$ 's waarmee NPK's op een standaardmutsnoemer worden gebracht, zijn uit de respectievelijke week-/maand-/jaar-WFI's afgeleide ratio's van het gemiddeld MNI voor de inkomensverandering.

\section{Beperkingen}

In twee opzichten lopen de 'nut'- en de 'winst'-dimensie van de analogie uiteen.
I Schaling van de externe meetlat voor de rekeneenheid

De marginale economische koopkracht is in principe constant voor een bepaalde valuta op een bepaald tijdstip. Derhalve volstaat één omrekenkoers of ratio van prijsindexcijfers voor alle bedragen van dezelfde valuta en/of datum.

Het MNI daarentegen neemt toe en dan af naarmate het inkomen toeneemt. Bijgevolg zijn de $\alpha$-ratio's afhankelijk van zowel de respectievelijke uitgangsinkomens als de bedragen op de respectievelijke NPK's in de specifieke situatie.

2 Subjectiviteit van de ijkprocedure

Valuta-omrekenkoersen en ratio's van prijsindexcijfers zijn op een door derden toetsbare wijze gebaseerd op situationele marktgegevens. In deze zin zijn zij minder subjectief dan $\alpha$-ratio's. inkomensevaluaties komen tot stand door een introspectief proces dat wegens de 'impossibility of communication between minds' niet waarneembaar is voor derden.

Echter, juist door zijn introspectieve karakter is inkomensnut voor iedere persoon een éénduidig gedefinieerd begrip. De financial accountant daarentegen dient (binnen de grenzen van de regelgeving) een - subjectieve - keuze te maken uit alternatieve definities van valuta-omrekenkoersen (historische versus actuele koersen) en prijsindexcijfers (consumentenprijsindex versus een $G N P$ deflator).

\section{Evaluatie}

Dat inkomensnut in tegenstelling tot economische koopkracht van het geld niet marginaal constant is, acht ik een zuiver technisch onderscheid zonder (nadelige) consequenties voor de validiteit en/of betrouwbaarheid van de IEQ/WFI. Eventuele meerkosten die het extra rekenwerk van de nutsvergelijking ten opzichte van valuta-omrekeningen en koopkrachtcorrecties met zich mee zou brengen, zijn een potentieel argument tegen de economische operationaliseerbaarheid van de welvaartstheoretische modellen; voor de technische operationaliseerbaarheid is het kostenaspect niet relevant.

Van de verschillen ten aanzien van de subjectiviteit van de ijkprocedure verwacht ik dat deze bepalend zullen zijn voor de houding van traditionele accountants jegens de IEQ/WFI. In feite hebben wij te maken met twee soorten subjectiviteit: subjectiviteit in de zin van onverifieerbaarheid van de inkomensevaluaties, waarvan de oorzaak bij de IEQ-respondent ligt; 
subjectiviteit in de zin van dubbel-innige definities van valuta-omrekenkoersen en prijsindexcijfers, waarvan de oorzaak bij de accountant ligt.

Mijns inziens is op dit punt sprake van een 'wetenschappelijke medaille'. De aanvaardbaarheid van de IEQ/WFI als onderdeel van de welvaartstheoretische maatschappelijke berichtgeving staat of valt met van welke kant men deze medaille bekijkt.

Wie deel uitmakt van de groeiende groep accountants die relevantie als de belangrijkste eigenschap van accounting informatie beschouwen, zal geneigd zijn - althans in afwachting van verder onderzoek - de IEQ/WFI het voordeel van de twijfel te geven.

Aanhangers van de traditionele opvatting dat accounting informatie vooral objectiveerbak dient te zijn, zullen daarentegen vermoedelijk trachten nutsvergelijking en de IEQ/WFI buiten de poorten van de maatschappelijke berichtgeving te houden

Daar ik mijzelf tol de eerste categorie reken. stel ik vast dat de IEQ/WFI de welvaartstheoretische matschappelijke berichtgeving over de drempel van de technische operationaliseerbaarheid heeft getrokken.

\section{De welvaartstheoretische benadering: vooruitzichten op volledige rehabilitatic}

In hoeverre financial accountants deze mening zullen delen word in belangrijke mate bepaald door hun oordeel over nutsvergelijking met behulp van de IEQ/WFI. Echter, de neutralisatie van verschillen in inkomensnut is slechts één stap in het maatschappelijk waarderingsproces. De opgegeven NPK-bedragen zijn naar hun aard evenmin rechtstreeks verifieerbaar als de inkomensevaluaties, maar anderzijds moet men de subjectieve elementen van de financiële verslaggeving niet onderschatten. Hierbij valt bijvoorbeeld te denken aan de keuze van een waarderingsgrondslag of afschrijvingsstelsel (vooral in verband met buitenlandse beursnotering), dan wel aan de bepaling van de omvang van een voorziening. Bij de bepaling van de besluitvormingscontext-B's (zie paragraaf 4) zullen vermoedelijk soortgelijke politieke overwegingen een rol spelen als bij een bedrijfseconomische kosten/baten-analyse.

Evenals onder meer Estes (1976, p. 156) meen ik dat integraal-financiële maatschappelijke berichtgeving - voorzover mogelijk - dezelfde kwalitatieve eigenschappen behoort te bezitten als traditionele accountinginformatie. Bij de ontwikkeling van een rekeningsysteem voor de kwaliteit van de arbeid (Teplá, 1996, hoofdstuk 7) ben ik dan ook uitgegaan van de eisen van het traditionele normatieve raamwerk. Over het algemeen acht ik de vereiste eigenschappen in voldoende mate aanwezig. Echter, zowel de toetsing als de analogie wezen uit dat de lat inzake de verifieerbaarheid (vooralsnog) enigszins lager moet worden gelegd dan bij de 'gewone' financiële verslaggeving.

Of de kosten/baten en gedragseffecten van implementatie uiteindelijk zullen bijdragen aan een hoger werknemerswelzijn en lagere arbeidskosten voor zowel onderneming als maatschappij, zal enkel praktische toepassing kunnen uitwijzen. Bij de empirische toetsing van de haalbaarheid van hel hybride-welvaartstheoretische model zou de indicatorenbenadering - de meest geavanceerde vorm van sociale berichtgeving tot dusver qua kosten/baten en gedragseffecten als benchmark kunnen dienen.

\section{LITERAT U UR}

Agho, A.O., J.L. Price en C.W. Mueller, (1992), Discriminant Validity of Measures of Job Satisfaction, Positive Affectivity and Negative Affectivity, In: Journal of Occupational and Organizational Psychology, vol. 65, pp. 185-196.

Antonides, G., A. Kapteyn en T.J. Wansbeek, (1980), Reliability and Validity Assessment of Ten Methods for the Measurement of Welfare Functions of Income, working paper, Modelling Research Group, University of Southern California.

Bulte, J. en R. van der Wal, (1986), 5yllabus Doctoraal Basisstof Kostenvraagstukken 1986-1987, Erasmus Universiteit Rotterdam.

Coombs, C.H., (1967), Psychological scaling without a unit of measurement, In: $M$. Fishbein (red.), Readings in attitude theory and measurement, John Wiley en Sons, Inc., New York/London/Sydney, pp. 117-124.

Dasgupta, A.K. en D.W. Pearce, (1972), Cost-Benefit Analysis Theory en Practice, Macmillan Student Editions.

Dekker, H.C., Social Accounting, (1992), In: A.D. Bac, A.J. Bindenga, J.C.A. Gortemaker, H.C. Kocks en K.P.G. Wilschut (red.), Handboek Accountancy, Samsom Bedrijfsinformatie bv, Alphen aan den Rijn (losbladig).

Eichhorn, P., (1974a), Grundlagen einer gemeinwirtschaftlichen Erfolgsrechnung für Unternehmen, Schriftenreihe Gemeinwirtschaft, Nr.15, Frankfurt am Main/Köln.

Eichhorn, P., (1974b), Gesel/schaftsbezogene Unternehmens- 
rechnung, Schriften der Kommission für wirtschaftlichen und sozialen Wandel, Nr.30, Gottingen.

Estes, R., (1976), Corporate Social Accounting, John Wiley en Sons, Inc., New York.

Goudzwaard, B., (1970), Ongeprijsde Schaarste - een onderzoek naar de plaats van expretiale of ongecompenseerde effekten in de theoretische economie en de leer der economische politiek, proefschrift, Erasmus Universiteit Rotterdam, Den Haag: Van Stockum.

Gray, R., D. Owen en K. Maunders, (1987), Corporate Social Reporting - Accounting and Accountability, Prentice-Hall International (UK) Ltd.

Hartog, F., (1973), Toegepaste Welvaartseconomie, 2e herziene druk, H.E. Stenfert Kroese BV, Leiden.

Hoevenagel, R., (1994), The Contingent Valuation Method Scope and Validity, proefschrift, Institute for Environmental Studies (IVM), Vrije Universiteit, Amsterdam.

Kapteyn, A. en T. Wansbeek, (1985), The Individual Welfare Function - A Review, In: Journal of Economic Psychology, vol. 6, pp. 333-363.

Locke, E.A., (1969), What Is Job Satisfaction?, In: Organizational Behavior and Human Performance, vol. 4, pp. 309-336.

Luce, D. en H. Raiffa, (1957), Games and Decisions - Introduction and Critical Survey, Wiley and Sons, Inc., New York.

Milne, M.J., (1991), Accounting, Environmental Resource Values, And Non-Market Valuation Techniques For Environmental Resources - A Review, In: Accounting, Auditing en Accountability Journal, vol. 4, no. 3, pp. 81-109.

Nath, S.K., (1969), A Reappraisal of Welfare Economics, Routledge \& Kegan Paul, London.

Nath, S.K., (1973), A Perspective of Welfare Economics, Macmillan, London.

Praag, B.M.S. van, (1971), The Welfare Function of Income in Belgium - An Empirical Investigation, In: European Economic Review, vol. 2, no. 3, Spring, pp. 337-369.

Praag, B.M.S. van, (1989), Ordinal and Cardinal Utility - An Integration of the Two Dimensions of the Utility Concept. Rapport 9019/A, Econometrisch Instituut, Erasmus Universiteit Rotterdam, December

Praag, B.M.S. van en A. Kapteyn, (1973), Further Evidence on the Individual Welfare Function of Income - An Empirical Investigation in The Netherlands, In: European Economic Review, vol. 4, pp. 33-62.

Samuelson, P.A., (1977), Reaffirming the Existence of 'Reasonable' Bergson-Samuelson Social Welfare Functions, In: Economica, vol. 44, pp. 81-88.

Sar, N.L. van der, (1991), Applied Utility Analysis, proefschrift, Erasmus Universiteit Rotterdam, Offsetdrukkerij Haveka B.V., Alblasserdam.

Sar, N.L. van der, en B.M.S. van Praag, (1993), The Evaluation Question Approach - A method of measuring attitudes, In: Journal of Economic Psychology, vol. 14, pp. 183-201.

Schreuder, H., (1981), Maatschappelijke verantwoordeliikheid en maatschappelijke berichtgeving van ondernemingen,

H.E. Stenfert Kroese, Leiden.

Schreuder, H., (1979), Corporate Social Reporting in the Federal

Republic of Germany - An Overview, In: Accounting,

Organizations and Society, vol. 4, no. 1/2, pp. 109-122.

Seashore, S.E., (1974), Job Satisfaction as an Indicator of the

Quality of Employment, In: Social Indicators Research,

vol. 1, pp. 135-168.

Seidler, L.J., (1973), Dollar Values in the Income Statement, In:

L.J. Seidler en L.L. Seidler (red.), Social Accounting - Theory,

Issues and Cases, Melville, Los Angeles, 1975, pp. 1-13.

Solomons, D., (1974), Corporate Social Preferences - A New

Dimension in Accounting Reports?, In: H. Edey en B.S.

Yarney (red.), Debits, Credits, Finance and Profits, Sweet \&

Maxwell, London, 1974, pp. 131-141.

Tepla, K., (1994), Operationele Welvaartstheoretische Societal

Accounting Modellen in Zicht?, In: Pacioli Journaal, 7e jrg.,

no. 3, mei, pp. 27-31.

Teplá, K., (1996), Accounting for the Quality of Work-Life -

Putting Price Tags on Sources of Job Dissatisfaction, proefschrift, Tinbergen Instituut/Erasmus Universiteit Rotterdam, Thesis Publishers, Amsterdam.

\section{NOT E N}

1 In de VS betekent social accounting doorgaans maatschappelijke berichtgeving. In Europa gebruikt men deze term dikwijls voor de sociale berichtgeving (het deel van de maatschappelijke berichtgeving dat betrekking heeft op de kwaliteit van de arbeid) en wordt de maatschappelijke berichtgeving als geheel societal accounting genoemd.

2 Het begrip 'maatschappelijke kosten en baten' wordt hier gebezigd in de 'waarderingsbetrekking' van Goudzwaard (1970, pp. 13-14). Externe effecten noemt Goudzwaard 'kosten [en baten] in een benadelingsbetrekking' (1970, pp. 14-15).

3 Een cardinale schaal wordt gekenmerkt door gelijke intervallen en een vast nulpunt. Hierdoor mogen alle wiskundige bewerkingen (optellen, aftrekken, vermenigvuldigen en delen) zowel op de absolute schaalwaarden als op de afstanden ertussen worden toegepast (Coombs, 1967, p. 122).

4 Omdat de ethical observer in termen van zijn of haar eigen inkomensmut denkt, is $\alpha$ per definitie gelijk aan 1.

5 De hypothetische-marktconstructie, waarbij het effect in termen van een 'schaars goed' wordt geformuleerd, is een noodzakelijke voorwaarde voor het gebruik van geld als economische meeteenheid

6 Dit voorbeeld is ontleend aan de Nederlandse samenvatting van mijn proefschrift (Tepla, 1996, pp. 561-563). In de voorlaatste alinea van het antwoord op vraag 53 zijn bij de berekening van de $\mathrm{MNI}$ 's enkele decimaalnullen weggevallen, maar de einduitkomst (waarde van B's $\alpha$ ) klopt. 